The National Red Cross and Red Crescent Societies are called upon to avail themselves of the opportunities for compensation provided by the Fund for the benefit of their deserving members.

Those interested should contact the Board of the French Fund Maurice de Madre, at the ICRC in Geneva, or the ICRC delegations throughout the world for information on the procedure to follow when submitting a request for a grant.

\title{
The Central Tracing Agency Today
}

The new building of the ICRC's Central Tracing Agency (CTA) was recently officially opened in Geneva; this is an appropriate opportunity to review the latest developments in the Agency's activities and organization.

What is the specific role of the Central Tracing Agency and what are its activities? The CTA has been in operation for more than one hundred years and has a central card index which today contains more than 60 million information cards on about 40 million people. In 1984, some 340,000 requests for or items of information were received and registered. In broad terms, one can say that it is responsible for collecting, storing and transmitting information on victims of conflicts. In this way, it helps to alleviate the moral suffering of people in distress.

Moreover, thanks to its family message service, the CTA transmits messages of a humanitarian character between people cut off from normal means of communication.

Every year, as a consequence of international conflicts, civil wars or internal disturbances, thousands of people - soldiers and civilians, refugees and detainees, adults and children-are imprisoned, deported, suddenly uprooted from their homes, with no means of communicating even with their immediate family. For such people, the Red Cross often represents the only hope of receiving-some day-news from their families.

In order to ensure optimum preservation and use of the wealth of data collected by the Agency over more than a century, the old documents are today microfilmed and information gathered in 
current conflicts is put on computer file. The new building provides the essential space and equipment: the central card index is on the top floor, where daylight streams in through glass walls. The dataprocessing and microfilm services have been set up in offices with the most modern equipment.

Since its creation during the Franco-Prussian war of 1870-1871 until the 1960s, the Central Tracing Agency, which has had various names throughout its history, primarily served as a central secretariat receiving and transmitting personal or family information between belligerent parties.

In 1969, the situation changed. For the first time, ICRC delegates were especially trained and sent on mission in the field. Since then, Tracing Agency activities have been an integral part of the ICRC delegations' work.

Furthermore, the increase in ICRC activities made it necessary to step up the recruitment of personnel, whilst placing more emphasis on the greatest possible versatility in their qualifications. The Agency had to have personnel available to leave on mission abroad and work as a delegate or secretary in a delegation or, conversely, other departments at the ICRC had to have on hand staff able to back up CTA personnel when necessary, at headquarters or in the field.

This change in approach has led to a new generation of young delegates able to leave on mission abroad at a moment's notice.

In 1981, the Committee became aware that further changes had to be made and adapted the CTA's internal structure to the new requirements. The first stage consisted in appointing heads of divisions, employing data processing, promoting training courses, internally and externally (both on the specific working methods of the Agency and on subjects such as knowledge of languages, business management and the microfilming of documents) and setting up a documentation centre.

Efforts were made to examine, in the light of past experience, the doctrine and principles which govern, in the context of the Geneva Conventions, the Agency's work and to develop closer co-operation with the National Societies, which are the CTA's natural partners. All this reflects the new impetus in the Agency's work. 
In November 1982, the Agency organized an International Technical Seminar ${ }^{1}$; representatives from about fifty National Societies assembled in Geneva to discuss matters relative to the Agency's activities. This was the first time such a seminar took place. It met with a very favourable response from the National Societies and proved to be extremely useful in deciding on a number of guidelines which will, we hope, facilitate the work of all concerned and more clearly define means of co-operation on an international level in CTA activities.

The CTA had set up a working group to prepare the seminar and it soon became apparent that an important follow-up was necessary. A small unit was thus created, the PAM (Principles and Methods) unit, made up of several experienced CTA staff members and reporting directly to the head of the Agency, to reappraise and conduct research on several aspects of the Agency's principles and methods of work. The group also has the task of following up a number of wishes expressed by National Societies during the international seminar, taking into account the ICRC's overall desire to reinforce co-operation with the National Societies.

Besides analysing the debates held during the first seminar of November 1982 and drawing up a final report on the meeting, the group has worked since then to compile a manual on the CTA's principles and methods of work. ${ }^{1}$

A Guide for use by the National Societies is going to be published. It should enable the co-operation which already exists to be improved and help each National Society in developing its own tracing service.

Faced as it is by new challenges the ICRC is endeavouring, by improving each of its services, to fulfil the mandate entrusted to it by the international community.

'See International Review of the Red Cross, January-February 1983. 